\title{
INDEX TO VOLUME 20 (2002)
}

\section{Articles}

BALANDIER, Georges. La Situation coloniale: ancien concept, nouvelle réalité (Vol. 20, No. 2, p. 4)

BEAUD, Stéphane and MASCLET, Olivier. Réflexions sur la trajectoire des terroristes présumés (Vol. 20, No. 2, p. 159)

BERGER, Suzanne. French Democracy Without Borders (Vol. 20, No. 1, p. 1)

CONKLIN, Alice. The New "Ethnology" and "la situation coloniale" in Interwar France (Vol. 20, No. 2, p. 29)

COOPER, Fred. Decolonizing Situations: The Rise, Fall, and Rise of Colonial Studies, 1951-2001 (Vol. 20, No. 2, p. 47)

HOEFERT DE TURÉGANO, Teresa. The New Politics of African Cinema at the French Ministry of Foreign Affairs (Vol. 20, No. 3, p. 22)

JELEN, Brigitte. 17 octobre 1961 - 17 octobre 2001: Une commémoration ambiguë (Vol. 20, No. 1, p. 30)

MERLE, Isabelle. Réflexions autour du régime de l'indigénat (Vol. 20, No. 2, p. 77)

POUILLON, François. A Century and a Half of Algerian Painting: Relevance for Understanding the Post-Colonial Situation (Vol. 20, No. 2, p. 141)

RAFFIN, Anne. Easternization Meets Westernization: Patriotic Youth Organizations in French Indochina during World War II (Vol. 20, No. 2, p. 121)

SAADA, Emmanuelle. The Empire of Law: Dignity, Prestige and Domination in the Colonial Situation (Vol. 20, No. 2, p. 98)

SABBAGH, Daniel. Affirmative Action at Sciences Po (Vol. 20, No. 3, p. 52)

SIBEUD, Emmanuelle. L'Ethnographie africainiste entre "inauthenticité" et empathie coloniale (Vol. 20, No. 2, p. 11)

TRUMBULL, Gunnar. Policy Activism in a Globalized Economy: France's 35-hour Workweek (Vol. 20, No. 3, p. 1)

VOGEL, David and BENSEDRINE, Jabril. Comparing Risk Regulation in the United States and France: Asbestos, Aids and Genetically Modified Agriculture (Vol. 20, No. 1, p.13)

ZØLNER, Mette. French E-Managers: A Generation in the Making (Vol. 20, No. 3, p. 33)

\section{Dossier: Women And Politics}

CAPDEVIELLE, Jacques. La Construction européenne confrontée aux attentes des Françaises (Vol. 20, No. 1, p. 58) 
GASPARD, Françoise. Des élections municipales sous le signe de la parité (Vol. 20, No. 1, p. 44)

\section{Dossier: Norbert Élias AND THE French}

GORDON, Daniel. The Canonization of Norbert Élias in France: A Critical Perspective (Vol. 20, No. 1, p. 68)

CHARTIER, Roger. The Oldest Hath Borne Most: Response to Daniel Gordon (Vol. 20, No. 1, p. 95)

GORDON, Daniel. A Reply (Vol. 20, No. 1, p. 100)

\section{Dossier: Race and Immigration in Interwar France}

DEWHURST LEWIS, Mary. The Strangeness of Foreigners: Policing Migration and Nation in Interwar Marseille (Vol. 20, No. 3, p. 65)

ROSENBERG, Clifford. Albert Sarraut and Republican Racial Thought (Vol. 20, No. 3, p. 97)

\section{ForUm: LA RELIGION DANS LA DÉMOCRATIE: PARCOURS DE LA LAÏCITÉ}

ANTOINE, Agnès. La Conscience religieuse dans l'ère de la laïcité (Vol. 20, No. 3, p. 115) BADONE, Ellen. Identity and Democracy (Vol. 20, No. 3, p. 121)

HERVIEU-LÉGER, Danièle. Sortie de la religion et recours à la transcendance (Vol. 20, No. 3, p. 126)

\section{Review EsSAys}

BOUDIC, Goulven. Connaissez-vous Jacques Nantet? (Vol. 20, No. 1, p. 101)

GRÉMION, Pierre. Les Guerres froides intellectuelles: une lecture française (Vol. 20, No. 1, p.111)

\section{Book Reviews}

AMBLER, John. Schools and Work: Technical and Vocational Education in France Since the Third Republic by Charles R. Day (Vol. 20, No. 2, p. 175)

BERTHO LAVENIR, Catherine. Marketing Michelin: Advertising and Cultural Identity in Twentieth-Century France by Stephen L. Harp (Vol. 20, No. 3, p. 135)

BULLARD, Alice. The Colonial Bastille: A History of Imprisonment in Vietnam, 1862-1940 by Peter Zinoman (Vol. 20, No. 1, p. 128)

CLAYSON, Hollis. Impressionists and Politics: Art and Democracy in the Nineteenth Century by Philip Nord (Vol. 20, No. 1, p. 125)

COHEN, Daniel G. The Legacy of Nazi Occupation: Patriotic Memory and National Recovery in Western Europe, 1945-1965 by Pieter Lagrou (Vol. 20, No. 1, p. 140) 
COHEN, Daniel G. Xavier Vallat: Du nationalisme chrétien à l'antisémitisme d'état, 18911972 by Laurent Joly (Vol. 20, No. 2, p. 173)

GENOVA, James E. Expériences coloniales: La Nouvelle-Calédonie (1853-1920) by Isabelle Merle (Vol. 20, No. 2, p. 171)

GRUNBERG, Gérard. François Mitterrand: The Last French President by Ronald Tiersky (Vol. 20, No. 3, p. 142)

KSELMAN, Thomas. Educating the Faithful: Religion, Schooling, and Society in NineteenthCentury France by Sarah A. Curtis (Vol. 20, No. 1, p. 122)

MILLER, Michael. Cette vilaine affaire Stavisky: Histoire d'un scandale politique by Paul Jankowski, trans. Patrick Hersant (Vol. 20, No. 1, p. 132)

MOTTE, Warren. French Fiction in the Mitterrand Years: Memory, Narrative, Desire by Colin Davis and Elizabeth Fallaize (Vol. 20, No. 1, p. 145)

NORD, Philip. Les Orphelins de la République: Destinées des députés et sénateurs français (1940-1945) by Olivier Wieviorka (Vol. 20, No. 1, p. 135)

PAXTON, Robert O. France: The Dark Years, 1940-44 by Julian Jackson and Marianne in Chains by Robert Gildea (Vol. 20, No. 3, p. 139)

SCHAIN, Martin A. The Dignity of Working Men by Michèle Lamont and Public Attitudes Toward Immigration in the United States, France and Germany by Joel S. Fetzer (Vol. 20, No. 3, p. 145)

THOMPSON, Christopher S. "Être Rugby": Jeux du masculin et du féminin by Anne Saouter (Vol. 20, No. 1, p. 148)

VINCENT, Steven K. Victor Considérant and the Rise and Fall of French Romantic Socialism by Jonathan Beecher (Vol. 20, No. 1, p. 120)

WALTON, Whitney. The Virtuous Marketplace: Women and Men, Money and Politics in Paris, $1830-1870$ by Victoria E. Thompson (Vol. 20, No. 3, p. 132)

\section{Film Review}

WASKIEWICZ, Sylvie. Le Fabuleux Destin d'Amélie Poulain by Jean-Pierre Jeunet (Vol. 20, No. 1, p. 152) 


\section{INDEX OF BOOKS REVIEWED}

BEECHER, Jonathan. Victor Considérant and the Rise and Fall of French Romantic Socialism reviewed by Steven K. Vincent (Vol. 20, No. 1, p. 120)

CURTIS, Sarah A. Educating the Faithful: Religion, Schooling, and Society in NineteenthCentury France reviewed by Thomas Kselman (Vol. 20, No. 1, p. 122)

DAVIS, Colin and FALLAIZE, Elizabeth. French Fiction in the Mitterrand Years: Memory, Narrative, Desire reviewed by Warren Motte (Vol. 20, No. 1, p. 145)

DAY, Charles R. Schools and Work: Technical and Vocational Education in France Since the Third Republic reviewed by John Ambler (Vol. 20, No. 2, p. 175)

FETZER, Joel S. Public Attitudes Toward Immigration in the United States, France and Germany reviewed by Martin A. Schain (Vol. 20, No. 3, p. 145)

GILDEA, Robert. Marianne in Chains reviewed by Robert O. Paxton (Vol. 20, No. 3, p. 139)

HARP Stephen L. Marketing Michelin: Advertising and Cultural Identity in TwentiethCentury France reviewed by Catherine Bertho Lavenir (Vol. 20, No. 3, p. 135)

JACKSON, Julian. France: The Dark Years, 1940-44 reviewed by Robert O. Paxton (Vol. 20, No. 3, p. 139)

JANKOWSKI, Paul. Cette vilaine affaire Stavisky: Histoire d'un scandale politique, trans. Patrick Hersant, reviewed by Michael Miller (Vol. 20, No. 1, p. 132)

JOLY, Laurent. Xavier Vallat: Du nationalisme chrétien à l'antisémitisme d'état, 18911972 reviewed by Daniel G. Cohen (Vol. 20, No. 2, p. 173)

LAGROU, Pieter. The Legacy of Nazi Occupation: Patriotic Memory and National Recovery in Western Europe, 1945-1965 reviewed by Daniel G. Cohen (Vol. 20, No. 1, p. 140)

LAMONT, Michèle. The Dignity of Working Men reviewed by Martin A. Schain (Vol. 20, No. 3, p. 145)

MERLE, Isabelle. Expériences coloniales: La Nouvelle-Calédonie (1853-1920) reviewed by James E. Genova (Vol. 20, No. 2, p. 171)

NORD, Philip. Impressionists and Politics: Art and Democracy in the Nineteenth Century reviewed by Hollis Clayson (Vol. 20, No. 1, p. 125)

SAOUTER, Anne. "Être Rugby": Jeux du masculin et du féminin reviewed by Christopher S. Thompson (Vol. 20, No. 1, p. 148)

THOMPSON, Victoria E. The Virtuous Marketplace: Women and Men, Money and Politics in Paris, 1830-1870 reviewed by Whitney Walton (Vol. 20, No. 3, p. 132)

TIERSKY, Ronald. François Mitterrand: The Last French President reviewed by Gérard Grunberg (Vol. 20, No. 3, p. 142)

WIEVIORKA, Olivier. Les Orphelins de la République: Destinées des députés et sénateurs français (1940-1945) reviewed by Philip Nord (Vol. 20, No. 1, p. 135)

ZINOMAN, Peter. The Colonial Bastille: A History of Imprisonment in Vietnam, $1862-$ 1940 reviewed by Alice Bullard (Vol. 20, No. 1, p. 128) 